\title{
F-AlCoPdGe Alloy with Three Types of Pseudo-Mackay Clusters
}

\author{
K. Sugiyama*, K. Yubuta, Y. Yokoyama, S. Suzuki and R. Simura \\ Institute for Materials Research (IMR), Tohoku University, Sendai, Japan
}

\begin{abstract}
The structure of an F-AlCoPdGe alloy was determined by single-crystal X-ray diffraction analysis: space group $P a \overline{3}$ (No. 205), Pearson symbol $c P 1128-142.4, a=24.4338(4) \AA ; R 1=0.0526$ for the observed 5106 reflections with $F_{0}>4.0 \sigma\left(F_{0}\right)$. The $F$-AlCoPdGe alloy exhibited three types of pseudo-Mackay clusters (pMCs). The first shell of the $\mathrm{Co}(13)$-pMC at $24 d$ indicated a coordination polyhedron typically found in Al-Co binary approximants; the second shell was a combination of an $\mathrm{M}$ icosahedron and an $\mathrm{Al}$ icosidodecahedron, where $\mathrm{M}$ is a mixed site of $\mathrm{Pd}$ and/or Co. The first shell of the $\mathrm{Co}(14)-\mathrm{pMC}$ at $4 b$ consisted of 20 partially occupied $\mathrm{Al}$ positions arranged in a dodecahedral fashion; its second shell was also composed of an $\mathrm{M}$ icosahedron and an Al icosidodecahedron. The first shell of the $\mathrm{Al}(18)-\mathrm{pMC}$ at $4 a$ consisted of a combination of an $\mathrm{M}$ cube and an $\mathrm{Al}$ octahedron, resulting in the rhombic dodecahedral arrangement; its outer shell structure was similar to those of the other pMCs. The structure of the $F$-AlCoPdGe phase comprised an arrangement of these three types of pMCs together with interstitially placed $\mathrm{Al}$ icosahedra around the $\mathrm{Pd} / \mathrm{Al}(1)$ and $\mathrm{Pd} / \mathrm{Al}(2)$ sites.
\end{abstract}

DOI: 10.12693/APhysPolA.126.588

PACS: 61.66.Dk, 61.05.cp, 61.44.Br

\section{Introduction}

Numerous complex intermetallic compounds have been reported as existing in the binary and ternary alloy systems of $\mathrm{Al}$ and transition metals. The $\mathrm{Al}-\mathrm{Co}-\mathrm{Pd}$ system is one of the most interesting alloy systems since a variety of crystalline phases associated with quasicrystals has been reported in conventionally solidified samples of this system [1]. Of the various crystalline phases noticed in the samples, the $\varepsilon$-phases have structures similar to that of the $\mathrm{Al}_{3} \mathrm{Pd}$ ( $\varepsilon_{6}$-phase), which is an important crystalline approximant of decagonal quasicrystals with a period of $1.6 \mathrm{~nm} \mathrm{[2].} W$-AlCoPd containing approximately 5 at.\% Pd exhibits cell parameters similar to those of $W-\mathrm{AlCoNi}[3]$, and its structural characteristics are useful for understanding those of the columnar unit in the decagonal phase with a periodicity of $0.8 \mathrm{~nm}$. On the other hand, a few crystalline phases probably associated with the icosahedral phase have also been found in this $\mathrm{Al}-\mathrm{Pd}-\mathrm{Co}$ system. The $C_{2}$ and $F$ phases can be classified as belonging to this category, although their structures have not yet been determined. R-AlPdCo [4] is another alloy of the $\mathrm{Al}-\mathrm{Co}-\mathrm{Pd}$ system; its structure shows the presence two types of pseudo-Mackay clusters (pMCs) similar to those found in $1 / 1-\mathrm{AlCuRu}[5]$ and trigonal $\chi$-AlPdRe [6]. In this context, a series of structural investigations on the intermetallic compounds in $\mathrm{Al}-\mathrm{Co}-\mathrm{Pd}$ system would aid in determining the characteristics of the columnar unit in the decagonal phase as well as the atom clusters of the icosahedral phase. In a study on the Al-Co-Pd system, the addition of Ge into a ternary $\mathrm{Al}-\mathrm{Co}-\mathrm{Pd}$ alloy was found to encourage the formation of the $F$ phase in a size large enough to allow for

*corresponding author; e-mail: kazumasa@imr.tohoku.ac.jp structural analysis. This paper describes the structure of the $F$-AlCoPdGe alloy as determined by single-crystal $\mathrm{X}$-ray diffraction analysis.

\section{Experimental}

An ingot of the alloy, which had a nominal composition of $\mathrm{Al}_{65} \mathrm{Co}_{20} \mathrm{Pd}_{10} \mathrm{Ge}_{5}$, was prepared from pure $\mathrm{Al}(99.999 \%), \mathrm{Co}(99.9 \%), \operatorname{Pd}(>99.95 \%)$, and $\mathrm{Ge}(>99.99 \%)$ in an atmosphere of purified Ar using a conventional arc melting furnace. A single-crystal specimen, which had the morphology of an elongated prism, was selected from the as-prepared ingot. The chemical composition of the specimen was determined by electron probe microanalysis (EPMA) (JEOL JXA-8621MX). The results indicated that the composition of the $F$ phase was $\mathrm{Al}_{67.9} \mathrm{Co}_{19.7} \mathrm{Pd}_{9.8} \mathrm{Ge}_{2.5}$ and quite similar to that of the starting alloy ingot. A block-shaped single crystal $44 \times 48 \times 65 \mu \mathrm{m}^{3}$ in size was cut from the alloy ingot and examined by single-crystal X-ray diffraction. Intensity data of 89172 reflections were collected using a Rigaku $R$-AXIS RAPID system and Mo $K_{\alpha}$ radiation $\left(2 \theta<54.9^{\circ}\right)$ [7]. After Lorentz and polarization corrections, an absorption correction was carried out by taking into account the shape of the specimen along with the absorption coefficient, which was estimated from the chemical composition and structural model of the alloy specimen [8]. The lattice constants suggested to select a cubic cell with $a=24.4338(4) \AA$. The observed reflections along with their intensity distribution led us to select the space group $P a \overline{3}$. Analyzing the data on the basis of this space group yielded 5580 independent reflections. Among these, 5106 reflections met the condition $F_{0}>4.0 \sigma\left(F_{0}\right)$.

The initial structural model was obtained by using the direct methods software package SIR97 [9]. The obtained structural model yielded 41 fully occupied sites; of these, 15 sites were suggested to be occupied by heavy met- 
Summary of experimental data.

TABLE I

\begin{tabular}{l|c}
\hline \hline chemical composition (EPMA) & $\mathrm{Al}_{67.9} \mathrm{Co}_{19.7} \mathrm{Pd}_{9.8} \mathrm{Ge}_{2.5}$ \\
chemical composition (X-RAY) & $\mathrm{Al}_{68.9} \mathrm{Co}_{18.7} \mathrm{Pd}_{11.1} \mathrm{Ge}_{1.3}$ \\
temperature $[\mathrm{K}]$ & $298(2)$ \\
wavelength $[\AA]$ & 0.71069 \\
space group & $P a \overline{3}$ \\
unit cell $[\AA]$ & $a=24.4338(4)$ \\
volume $\left[\AA^{3}\right]$ & $14587.2(7)$ \\
$D_{x}\left[\mathrm{Mg} / \mathrm{m}^{3}\right]$ & 4.750 \\
absorption coefficient $\left[\mathrm{mm}^{-1}\right]$ & 7.976 \\
$F(000)$ & 19237 \\
crystal size [mm $\left.{ }^{3}\right]$ & $0.044 \times 0.048 \times 0.065$ \\
$2 \theta_{\text {max }}\left[{ }^{\circ}\right]$ & 54.94 \\
$R_{\text {sigma }}$ & 0.0282 \\
$R_{\text {sigma }}$ & 0.0131 \\
$h, k, l$ & $-29<h<31$, \\
& $-31<k<30$, \\
no. of measured reflections & $-31<l<31$ \\
no. of independent reflections & 89196 \\
no. of observed reflections & 5580 \\
no. of parameters & 5106 \\
goodness-of-fit on $F^{2}$ & 393 \\
final $R$ indices $[I>2 \sigma(I)]$ & 1.031 \\
final $w R 2$ indices $($ all data) & 0.0526 \\
largest diff. peak and hole $\left[\mathrm{e} \AA^{3}\right]$ & 0.1366 \\
& 4.78 and -1.93 \\
&
\end{tabular}

als and the other 26 sites by Al. Each heavy metal site was surrounded by Al sites; this is a common feature in Al-based approximants of the binary $\mathrm{Al}-\mathrm{Pd}$ and $\mathrm{Al}-\mathrm{Co}$ systems $[2,10,11]$.

Calculating the interatomic distances allowed us to classify the heavy metal sites into two groups. The $\mathrm{Pd} / \mathrm{Al}(1)$ and $\mathrm{Pd} / \mathrm{Al}(2)$ sites were placed in the first group, which corresponded to nearest-neighbor distances of greater than $0.260 \mathrm{~nm}$. That the size of these two heavy metal sites was larger implied their preferred occupation by $\mathrm{Pd}$ and $\mathrm{Al}$ atoms. The nearest-neighbor distances of the other 13 heavy metal sites were less than $0.250 \mathrm{~nm}$; this strongly suggested that they were fully or partially occupied by Co atoms. The results of several least-squares calculations, performed using the software SHELXL-97 [12], prompted us to employ a chemically disordered model for the 15 heavy metal sites. Therefore, we continued the least-squares calculations by introducing two $\mathrm{Pd} / \mathrm{Al}$, ten $\mathrm{Co} / \mathrm{Pd}$, and three Co sites so as to obtain reasonable displacement parameters for the heavy metal sites (hereafter, the ten $\mathrm{Co} / \mathrm{Pd}$ and three Co sites are denoted as the $\mathrm{M}$ sites). A chemical disorder model was also introduced for the $\mathrm{Al} / \mathrm{Ge}(16)$ and $\mathrm{Al} / \mathrm{Ge}(17)$ sites because their displacement parameters became significantly smaller than the other $\mathrm{Al}$ sites when they were assumed to be fully occupied by $\mathrm{Al}$ atoms.

Difference Fourier maps obtained during the least-squares calculations indicated the presence of geometrically disordered areas in the present structural model. Next, four sets of partially occupied posi- tions, $\mathrm{Al}(42)(\mathrm{a}-\mathrm{b}), \mathrm{Al}(43)(\mathrm{a}-\mathrm{b}), \mathrm{Pd} / \mathrm{Ge} / \mathrm{Al}(44)(\mathrm{a}-\mathrm{c})$, and $\mathrm{Al}(45)(\mathrm{a}-\mathrm{d})$, were introduced. The displacement parameters for $\mathrm{Al}(45)(\mathrm{a}-\mathrm{d})$ sites were constrained to identical values. Further introduction of anisotropic displacement parameters for fully occupied sites converged at $R=0.0525$ for the observed 5106 reflections.

Experimental data are summarized in Table I. The final atomic coordinates and equivalent displacement parameters are listed in Tables II and III. The converged structural model yielded the following chemical composition: $\mathrm{Al}_{68.9} \mathrm{Co}_{18.7} \mathrm{Pd}_{11.1} \mathrm{Ge}_{1.3}$. The chemical composition of the structural model agreed fairly well with that determined by EPMA. It should be added that the ordinary application of single crystal X-ray diffraction could not allow us to specify the detailed structural role of Ge in the structure.

\section{Results and discussion}

The alloy $F$-AlCoPdGe exhibits three types of pMCs; the $\mathrm{Co}(13)-, \mathrm{Co}(14)-$, and $\mathrm{Al}(18)-\mathrm{pMCs}$. The pMCs with a central atom could be further classified into three types: those having a first shell with (1) partial icosahedral symmetry; (2) 3-fold symmetry, with the local 5-fold symmetry being lost; and (3) others [13]. The $\mathrm{Co}(13)-, \mathrm{Co}(14)-$, and $\mathrm{Al}(18)$-pMCs belong to types (3), (1), and (2), respectively. In particular, the $\mathrm{Co}(13)-\mathrm{pMC}$ is a typical example, having an irregularly shaped first shell, which has a smaller transition metal as the central atom, such as $\mathrm{Co}$ and Re. On the other hand, the $\mathrm{Al}(18)-\mathrm{pMC}$ is another fundamental structure with a larger central atom, such as $\mathrm{Al}$ and $\mathrm{Pd}$.

Figure 1 shows a pMC around $\mathrm{Co}(13)$ at the $24 d$ site $(\mathrm{Co}(13)-\mathrm{pMC})$. The first shell is an irregularly shaped polyhedron consisting of nine $\mathrm{Al}$ sites and some of the $\mathrm{Co}$ sites in binary $\mathrm{Al}-\mathrm{Co}$ phases exhibit a similar geometry $[10,11]$. The second shell has a radius of approximately $4.68 \AA$ and could be divided into two subshells. One is an icosahedron of $\mathrm{M}$ sites ( $\mathrm{M}$ icosahedron), with each vertex of the icosahedron being capped by five $\mathrm{Al}$ sites so as to form an $\mathrm{Al}$ icosidodecahedron. The $\mathrm{Co}(13)-\mathrm{pMC}$ is surrounded by four $\mathrm{Co}(13)-\mathrm{pMCs}$ by sharing the edges of the $\mathrm{M}$ icosahedron. At the same time, each pMC around the $\mathrm{Co}(14)$ and $\mathrm{Al}(18)$ sites also shares an icosahedral edge with the $\mathrm{Co}(13)$-pMC.

The first shell of the pMC around the $\mathrm{Co}(14)$ site is a dodecahedron consisting of statistically occupied $\mathrm{Al}(45)(\mathrm{a}-\mathrm{d})$ sites. Every site indicates the partial occupation and the concurrent occupation of the neighboring pairs are forbidden. Taking into account of the occupation parameters of these $\mathrm{Al}(45)(\mathrm{a}-\mathrm{d})$ sites, it can be said that approximately seven $\mathrm{Al}$ atoms are located around the $\mathrm{Co}(14)$ site. The size of the second shell is approximately $4.65 \AA$, and it is composed of an inner M icosahedron and an outer $\mathrm{Al}$ icosidodecahedron. Since this pMC shows a point symmetry of $\mathrm{Pa} \overline{3}$, the $\mathrm{Co}(14)$-pMC is surrounded by six $\mathrm{Co}(13)$-pMCs. The arrangement of atoms in the shell structure of the $\mathrm{Co}(14)-\mathrm{pMC}$ is shown in Fig. 2. 
TABLE II

Atomic coordinates and equivalent or isotropic displacement parameters of $F$-AlCoPdGe.

\begin{tabular}{|c|c|c|c|c|c|c|}
\hline Atom & site & occupation & $x$ & $y$ & $z$ & $U_{\text {eq }}\left[\AA^{2}\right]$ \\
\hline $\mathrm{Pd} / \mathrm{Al}(1)$ & $8 c$ & $0.74(1) / 0.26$ & $0.15660(3)$ & $x$ & $x$ & $0.0100(4)$ \\
\hline $\mathrm{Pd} / \mathrm{Al}(2)$ & $24 \mathrm{~d}$ & $0.68(1) / 0.32$ & $0.00180(3)$ & $0.40286(3)$ & $0.24813(3)$ & $0.0087(3)$ \\
\hline $\mathrm{Co} / \operatorname{Pd}(3)$ & $8 \mathrm{c}$ & $0.52(1) / 0.48$ & $0.25122(3)$ & $x$ & $x$ & $0.0085(5)$ \\
\hline $\mathrm{Pd} / \mathrm{Co}(4)$ & $24 \mathrm{~d}$ & $0.60(1) / 0.40$ & $0.00032(2)$ & $0.53709(2)$ & $0.59696(2)$ & $0.0051(2)$ \\
\hline $\mathrm{Pd} / \mathrm{Co}(5)$ & $8 \mathrm{c}$ & $0.48(1) / 0.52$ & $0.05987(3)$ & $x$ & $x$ & $0.0053(4)$ \\
\hline $\mathrm{Pd} / \mathrm{Co}(6)$ & $24 \mathrm{~d}$ & $0.56(1) / 0.44$ & $0.09648(3)$ & $0.50687(3)$ & $0.33981(3)$ & $0.0081(3)$ \\
\hline $\mathrm{Pd} / \mathrm{Co}(7)$ & $24 \mathrm{~d}$ & $0.48(1) / 0.52$ & $0.00598(3)$ & $0.65479(3)$ & $0.39532(3)$ & $0.0071(3)$ \\
\hline $\mathrm{Pd} / \mathrm{Co}(8)$ & $24 \mathrm{~d}$ & $0.35(1) / 0.65$ & $0.34258(3)$ & $0.09454(3)$ & $0.80629(3)$ & $0.0083(3)$ \\
\hline $\mathrm{Pd} / \mathrm{Co}(9)$ & $24 \mathrm{~d}$ & $0.31(1) / 0.69$ & $0.49989(3)$ & $0.15144(3)$ & $0.09840(3)$ & $0.0083(3)$ \\
\hline $\mathrm{Pd} / \mathrm{Co}(10)$ & $24 \mathrm{~d}$ & $0.31(1) / 0.69$ & $0.00016(3)$ & $0.35085(3)$ & $0.09115(3)$ & $0.0102(3)$ \\
\hline $\mathrm{Pd} / \mathrm{Co}(11)$ & $24 \mathrm{~d}$ & $0.24(1) / 0.76$ & $0.05222(3)$ & $0.24617(3)$ & $0.25092(3)$ & $0.0091(3)$ \\
\hline $\mathrm{Co}(12)$ & $24 \mathrm{~d}$ & 1 & $0.05927(4)$ & $0.05749(3)$ & $0.24953(3)$ & $0.0041(2)$ \\
\hline $\mathrm{Co}(13)$ & $24 \mathrm{~d}$ & 1 & $0.40281(4)$ & $0.15379(4)$ & $0.24537(4)$ & $0.0070(2)$ \\
\hline $\mathrm{Co}(14)$ & $4 \mathrm{~b}$ & 1 & 0 & 0 & $1 / 2$ & $0.0057(4)$ \\
\hline $\mathrm{Co}(15)$ & $24 \mathrm{~d}$ & 1 & $0.31215(4)$ & $0.15390(3)$ & $0.39810(4)$ & $0.0051(2)$ \\
\hline $\mathrm{Al} / \mathrm{Ge}(16)$ & $24 \mathrm{~d}$ & $0.84(1) / 0.16$ & $0.55864(7)$ & $0.09548(7)$ & $0.15827(7)$ & $0.0117(6)$ \\
\hline $\mathrm{Al} / \mathrm{Ge}(17)$ & $8 c$ & $0.89(1) / 0.11$ & $0.30927(7)$ & $x$ & $x$ & $0.012(1)$ \\
\hline $\mathrm{Al}(18)$ & $4 a$ & 1 & 0 & 0 & 0 & $0.0094(9)$ \\
\hline $\operatorname{Al}(19)$ & $24 \mathrm{~d}$ & 1 & $0.49873(9)$ & $0.19276(9)$ & $0.00239(9)$ & $0.0125(5)$ \\
\hline $\operatorname{Al}(20)$ & $24 \mathrm{~d}$ & 1 & $0.06129(9)$ & $0.21356(9)$ & $0.15532(9)$ & $0.0115(4)$ \\
\hline $\operatorname{Al}(21)$ & $24 \mathrm{~d}$ & 1 & $0.49727(9)$ & $0.00404(9)$ & $0.69403(9)$ & $0.0109(4)$ \\
\hline $\operatorname{Al}(22)$ & $24 \mathrm{~d}$ & 1 & $0.15298(9)$ & $0.24816(9)$ & $0.0933(1)$ & $0.0133(5)$ \\
\hline $\operatorname{Al}(23)$ & $24 \mathrm{~d}$ & 1 & $0.03622(9)$ & $0.55916(9)$ & $0.40228(9)$ & $0.0111(4)$ \\
\hline $\operatorname{Al}(24)$ & $24 \mathrm{~d}$ & 1 & $0.40729(9)$ & $0.46230(9)$ & $0.25242(9)$ & $0.0108(4)$ \\
\hline $\mathrm{Al}(25)$ & $24 \mathrm{~d}$ & 1 & $0.09835(9)$ & $0.65780(9)$ & $0.44342(9)$ & $0.0109(4)$ \\
\hline $\operatorname{Al}(26)$ & $24 \mathrm{~d}$ & 1 & $0.06351(9)$ & $0.09410(9)$ & $0.15591(9)$ & $0.0120(4)$ \\
\hline $\operatorname{Al}(27)$ & $24 \mathrm{~d}$ & 1 & $0.40244(9)$ & $0.15155(9)$ & $0.74812(9)$ & $0.0112(5)$ \\
\hline $\operatorname{Al}(28)$ & $24 \mathrm{~d}$ & 1 & $0.16047(9)$ & $0.55746(9)$ & $0.40557(9)$ & $0.0099(4)$ \\
\hline $\operatorname{Al}(29)$ & $24 \mathrm{~d}$ & 1 & $0.09520(9)$ & $0.34120(9)$ & $0.25214(9)$ & $0.0128(5)$ \\
\hline $\operatorname{Al}(30)$ & $24 \mathrm{~d}$ & 1 & $0.44147(9)$ & $0.09658(9)$ & $0.84298(9)$ & $0.0110(4)$ \\
\hline $\operatorname{Al}(31)$ & $24 \mathrm{~d}$ & 1 & $0.50198(9)$ & $0.31290(9)$ & $0.30968(9)$ & $0.0101(4)$ \\
\hline $\operatorname{Al}(32)$ & $24 \mathrm{~d}$ & 1 & $0.19490(9)$ & $0.00602(9)$ & $0.80867(9)$ & $0.0122(4)$ \\
\hline $\operatorname{Al}(33)$ & $24 \mathrm{~d}$ & 1 & $0.15217(9)$ & $0.24718(9)$ & $0.2163(1)$ & $0.0129(5)$ \\
\hline $\operatorname{Al}(34)$ & $24 \mathrm{~d}$ & 1 & $0.5975(1)$ & $0.4577(1)$ & $0.25205(9)$ & $0.0141(5)$ \\
\hline $\operatorname{Al}(35)$ & $24 \mathrm{~d}$ & 1 & $0.5617(1)$ & $0.40275(9)$ & $0.34359(9)$ & $0.0142(5)$ \\
\hline $\operatorname{Al}(36)$ & $24 \mathrm{~d}$ & 1 & $0.4860(1)$ & $0.1887(1)$ & $0.1961(1)$ & $0.0240(6)$ \\
\hline $\operatorname{Al}(37)$ & $24 \mathrm{~d}$ & 1 & $0.3191(1)$ & $0.1877(1)$ & $0.2981(1)$ & $0.0264(6)$ \\
\hline $\operatorname{Al}(38)$ & $24 \mathrm{~d}$ & 1 & $0.3391(1)$ & $0.1048(1)$ & $0.6230(1)$ & $0.0227(6)$ \\
\hline $\operatorname{Al}(39)$ & $24 \mathrm{~d}$ & 1 & $0.1609(1)$ & $0.4317(1)$ & $0.0994(1)$ & $0.0315(7)$ \\
\hline $\operatorname{Al}(40)$ & $24 \mathrm{~d}$ & 1 & $0.3030(1)$ & $0.0473(2)$ & $0.7143(2)$ & $0.056(1)$ \\
\hline $\mathrm{Al}(41)$ & $24 \mathrm{~d}$ & 1 & $0.3798(2)$ & $0.2435(2)$ & $0.2171(2)$ & $0.073(2)$ \\
\hline $\mathrm{Al}(42) \mathrm{a}$ & $24 \mathrm{~d}$ & $0.68(1)$ & $0.3607(2)$ & $0.0642(2)$ & $0.2467(2)$ & $0.038(1)^{*}$ \\
\hline $\mathrm{Al}(42) \mathrm{b}$ & $24 \mathrm{~d}$ & 0.32 & $0.3384(5)$ & $0.0816(5)$ & $0.2377(5)$ & $0.039(3)^{*}$ \\
\hline $\mathrm{Al}(43) \mathrm{a}$ & $24 \mathrm{~d}$ & $0.68(1)$ & $0.0239(2)$ & $0.5966(2)$ & $0.2705(2)$ & $0.023(1)^{*}$ \\
\hline $\mathrm{Al}(43) \mathrm{b}$ & $24 \mathrm{~d}$ & 0.32 & $0.0644(3)$ & $0.5578(3)$ & $0.2513(4)$ & $0.012(2)^{*}$ \\
\hline $\operatorname{Pd}(44) \mathrm{a}$ & $24 \mathrm{~d}$ & $0.47(1)$ & $0.15390(5)$ & $0.09680(5)$ & $0.30816(5)$ & $0.0136(4)^{*}$ \\
\hline $\mathrm{Ge}(44) \mathrm{b}$ & $24 \mathrm{~d}$ & $0.33(1)$ & $0.3435(1)$ & $0.15587(9)$ & $0.1573(1)$ & $0.0102(9)^{*}$ \\
\hline $\mathrm{Al}(44) \mathrm{c}$ & $24 \mathrm{~d}$ & $0.46(2)$ & $0.3315(3)$ & $0.1542(3)$ & $0.1866(4)$ & $0.040(3)^{*}$ \\
\hline $\mathrm{Al}(45) \mathrm{a}$ & $24 \mathrm{~d}$ & $0.39(2)$ & $0.0901(4)$ & $0.0034(4)$ & $0.4634(4)$ & $0.035(2)^{*}$ \\
\hline $\mathrm{Al}(45) \mathrm{b}$ & $24 \mathrm{~d}$ & $0.38(1)$ & $-0.0919(4)$ & $-0.0106(4)$ & $0.4602(4)$ & $0.035(2)^{*}$ \\
\hline $\mathrm{Al}(45) \mathrm{c}$ & $24 \mathrm{~d}$ & $0.31(2)$ & $-0.0580(4)$ & $-0.0562(4)$ & $0.4435(4)$ & $0.035(2)^{*}$ \\
\hline $\mathrm{Al}(45) \mathrm{d}$ & $8 c$ & $0.20(2)$ & $0.5549(7)$ & $x$ & $x$ & $0.035(2)^{*}$ \\
\hline
\end{tabular}

${ }^{*} U_{\text {iso }}\left[\AA^{2}\right]$ 
Anisotropic displacement parameters of $F$-AlCoPdGe.

TABLE III

\begin{tabular}{|c|c|c|c|c|c|c|}
\hline Atom & $U_{11}$ & $U_{22}$ & $U_{33}$ & $U_{23}$ & $U_{13}$ & $U_{12}\left[\AA^{2}\right]$ \\
\hline $\mathrm{Pd} / \mathrm{Al}(1)$ & $0.0100(4)$ & $U_{11}$ & $U_{11}$ & $-0.0001(2)$ & $U_{23}$ & $U_{23}$ \\
\hline $\mathrm{Pd} / \mathrm{Al}(2)$ & $0.0097(4)$ & $0.0085(4)$ & $0.0080(4)$ & $0.0002(2)$ & $-0.0012(2)$ & $-0.0007(2)$ \\
\hline $\mathrm{Pd} / \mathrm{Co}(3)$ & $0.0085(5)$ & $U_{11}$ & $U_{11}$ & $-0.0014(2)$ & $U_{23}$ & $U_{23}$ \\
\hline $\mathrm{Pd} / \mathrm{Co}(4)$ & $0.0058(3)$ & $0.0055(3)$ & $0.0041(3)$ & $-0.0003(2)$ & $0.0000(2)$ & $-0.0001(2)$ \\
\hline $\mathrm{Pd} / \mathrm{Co}(5)$ & $0.0053(4)$ & $U_{11}$ & $U_{11}$ & $-0.0004(2)$ & $U_{23}$ & $U_{23}$ \\
\hline $\mathrm{Pd} / \mathrm{Co}(6)$ & $0.0056(4)$ & $0.0096(4)$ & $0.0091(4)$ & $-0.0038(2)$ & $-0.0002(2)$ & $-0.0005(2)$ \\
\hline $\mathrm{Pd} / \mathrm{Co}(7)$ & $0.0069(4)$ & $0.0054(4)$ & $0.0091(4)$ & $-0.0004(2)$ & $-0.0024(2)$ & $0.0003(2)$ \\
\hline $\mathrm{Pd} / \mathrm{Co}(8)$ & $0.0083(4)$ & $0.0062(4)$ & $0.0104(4)$ & $0.0001(3)$ & $0.0041(3)$ & $0.0001(2)$ \\
\hline $\mathrm{Pd} / \mathrm{Co}(9)$ & $0.0077(4)$ & $0.0104(4)$ & $0.0067(4)$ & $0.0020(3)$ & $-0.0002(3)$ & $0.0024(3)$ \\
\hline $\mathrm{Pd} / \mathrm{Co}(10)$ & $0.0058(4)$ & $0.0153(5)$ & $0.0094(4)$ & $-0.0065(3)$ & $-0.0003(3)$ & $-0.0003(3)$ \\
\hline $\mathrm{Pd} / \mathrm{Co}(11)$ & $0.0110(5)$ & $0.0065(4)$ & $0.0097(5)$ & $0.0002(3)$ & $0.0043(3)$ & $0.0013(3)$ \\
\hline $\mathrm{Co} / \mathrm{Co}(12)$ & $0.0061(4)$ & $0.0039(4)$ & $0.0023(4)$ & $-0.0004(3)$ & $0.0003(3)$ & $-0.0027(3)$ \\
\hline $\mathrm{Co} / \mathrm{Co}(13)$ & $0.0080(4)$ & $0.0061(4)$ & $0.0070(4)$ & $-0.0004(3)$ & $0.0020(3)$ & $-0.0018(3)$ \\
\hline $\mathrm{Co}(14)$ & $0.0057(4)$ & $U_{11}$ & $U_{11}$ & $-0.0001(4)$ & $U_{23}$ & $U_{23}$ \\
\hline $\mathrm{Co}(15)$ & $0.0068(4)$ & $0.0030(4)$ & $0.0055(4)$ & $0.0002(3)$ & $-0.0007(3)$ & $-0.0012(3)$ \\
\hline $\mathrm{Al} / \mathrm{Ge}(16)$ & $0.012(1)$ & $0.013(1)$ & $0.0095(9)$ & $0.0039(6)$ & $0.0011(6)$ & $0.0016(6)$ \\
\hline $\mathrm{Al} / \mathrm{Ge}(17)$ & $0.012(1)$ & $U_{11}$ & $U_{11}$ & $-0.0015(6)$ & $U_{23}$ & $U_{23}$ \\
\hline $\mathrm{Al}(18)$ & $0.009(1)$ & $U_{11}$ & $U_{11}$ & $0.002(1)$ & $U_{23}$ & $U_{23}$ \\
\hline $\mathrm{Al}(19)$ & $0.014(1)$ & $0.014(1)$ & $0.009(1)$ & $0.0013(8)$ & $0.0019(8)$ & $0.0002(8)$ \\
\hline $\operatorname{Al}(20)$ & $0.014(1)$ & $0.012(1)$ & $0.009(1)$ & $-0.0012(8)$ & $-0.0018(8)$ & $0.0007(8)$ \\
\hline $\operatorname{Al}(21)$ & $0.010(1)$ & $0.012(1)$ & $0.011(1)$ & $0.0017(8)$ & $0.0030(8)$ & $-0.0009(8)$ \\
\hline $\operatorname{Al}(22)$ & $0.008(1)$ & $0.014(1)$ & $0.018(1)$ & $0.0007(9)$ & $0.0018(8)$ & $0.0039(8)$ \\
\hline $\operatorname{Al}(23)$ & $0.011(1)$ & $0.010(1)$ & $0.013(1)$ & $-0.0005(8)$ & $0.0009(8)$ & $0.0005(8)$ \\
\hline $\mathrm{Al}(24)$ & $0.014(1)$ & $0.009(1)$ & $0.010(1)$ & $0.0014(8)$ & $0.0023(8)$ & $-0.0015(8)$ \\
\hline $\operatorname{Al}(25)$ & $0.008(1)$ & $0.013(1)$ & $0.012(1)$ & $-0.0002(8)$ & $0.0013(8)$ & $0.0004(8)$ \\
\hline $\operatorname{Al}(26)$ & $0.014(1)$ & $0.013(1)$ & $0.009(1)$ & $0.0025(8)$ & $-0.0001(8)$ & $0.0012(8)$ \\
\hline $\operatorname{Al}(27)$ & $0.015(1)$ & $0.013(1)$ & $0.006(1)$ & $0.0029(8)$ & $0.0032(8)$ & $0.0012(8)$ \\
\hline $\operatorname{Al}(28)$ & $0.010(1)$ & $0.007(1)$ & $0.012(1)$ & $0.0004(8)$ & $-0.0009(8)$ & $-0.0009(7)$ \\
\hline $\operatorname{Al}(29)$ & $0.016(1)$ & $0.011(1)$ & $0.012(1)$ & $-0.0037(8)$ & $-0.0040(8)$ & $-0.0002(8)$ \\
\hline $\operatorname{Al}(30)$ & $0.012(1)$ & $0.009(1)$ & $0.013(1)$ & $-0.0018(8)$ & $-0.0018(8)$ & $-0.0009(8)$ \\
\hline $\operatorname{Al}(31)$ & $0.010(1)$ & $0.009(1)$ & $0.012(1)$ & $-0.0008(8)$ & $0.0023(8)$ & $-0.0006(8)$ \\
\hline $\mathrm{Al}(32)$ & $0.011(1)$ & $0.014(1)$ & $0.012(1)$ & $-0.0030(8)$ & $0.0000(8)$ & $0.0030(8)$ \\
\hline $\mathrm{Al}(33)$ & $0.013(1)$ & $0.012(1)$ & $0.014(1)$ & $-0.0004(8)$ & $-0.0010(8)$ & $0.0025(8)$ \\
\hline $\mathrm{Al}(34)$ & $0.017(1)$ & $0.016(1)$ & $0.009(1)$ & $-0.0011(8)$ & $0.0022(8)$ & $-0.0013(9)$ \\
\hline $\mathrm{Al}(35)$ & $0.020(1)$ & $0.011(1)$ & $0.012(1)$ & $0.0021(8)$ & $-0.0010(8)$ & $-0.0046(9)$ \\
\hline $\operatorname{Al}(36)$ & $0.030(1)$ & $0.024(1)$ & $0.018(1)$ & $-0.005(1)$ & $0.008(1)$ & $-0.014(1)$ \\
\hline $\operatorname{Al}(37)$ & $0.025(1)$ & $0.032(1)$ & $0.023(1)$ & $0.009(1)$ & $0.006(1)$ & $0.012(1)$ \\
\hline $\mathrm{Al}(38)$ & $0.016(1)$ & $0.022(1)$ & $0.031(1)$ & $-0.008(1)$ & $0.011(1)$ & $-0.006(1)$ \\
\hline $\mathrm{Al}(39)$ & $0.020(1)$ & $0.045(2)$ & $0.030(2)$ & $-0.020(1)$ & $-0.005(1)$ & $0.005(1)$ \\
\hline $\operatorname{Al}(40)$ & $0.030(1)$ & $0.087(3)$ & $0.053(2)$ & $0.042(2)$ & $-0.014(1)$ & $-0.004(2)$ \\
\hline $\operatorname{Al}(41)$ & $0.107(4)$ & $0.030(2)$ & $0.081(3)$ & $0.031(2)$ & $0.032(3)$ & $0.013(2)$ \\
\hline
\end{tabular}

The structure for another type of $\mathrm{Al}(18)-\mathrm{pMC}$, which is located at $4 \mathrm{a}$, is shown in Fig. 3. The first shell may be divided into two subshells of a cube of $\mathrm{M}(4)$ and $\mathrm{M}(5)$ and an octahedron of six $\operatorname{Al}(23)$ sites, by showing the local atomic arrangement of a rhombic dodecahedron. $\mathrm{Al}(23)$ is the vertex of the $\mathrm{Al}$ icosidodecahedron in the neighboring $\mathrm{Co}(13) \mathrm{pMC}$ and the $\mathrm{Al}(18)-\mathrm{pMC}$ is surrounded by six Co(13)-pMCs. The second shell can again be divided into two subshells: $\mathrm{M}$ icosahedron and an $\mathrm{Al}$ icosidodecahedron. The outer $\mathrm{Al}$ icosidodecahedron of the $\mathrm{Al}(18)-$ -pMC is heavily distorted and different from the other
pMCs around Co. This is owing to the size of its central atom together with the unique bcc arrangement of the first shell. It should be noted that this type of pMC is also found in the 1/1-cubic approximant structure of $R$-AlPdCo [6] and $\alpha$-AlCuRu [7].

Among the 17 heavy metal sites, the $\mathrm{Pd} / \mathrm{Al}(1)$ and $\mathrm{Pd} / \mathrm{Al}(2)$ sites are unique and are not the constituents of the three pMCs described above. Each of them is surrounded by $12 \mathrm{Al}$ atoms, forming a regular $\mathrm{Al}$ icosahedron. These two $\mathrm{Pd} / \mathrm{Al}$ icosahedra reside on the interstitial space of the pMCs since they share their peripheries. 
[i]

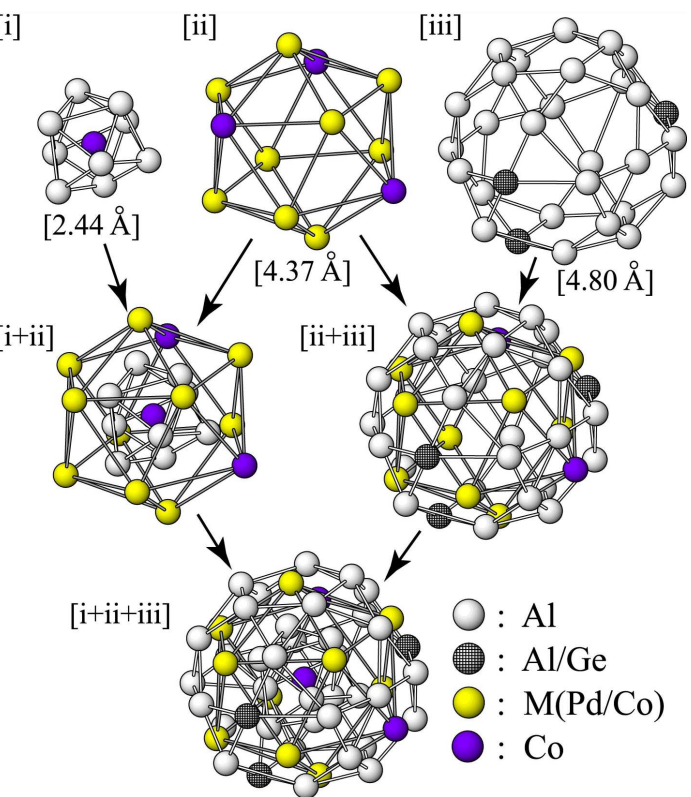

Fig. 1. The pseudo-Mackay cluster around the $\mathrm{Co}(13)$ site. The values in the parentheses are the averaged distances of the constituents from the central $\mathrm{Co}(13)$ atom. Some forbidden pairs with short distances arise from statistical disorder of several atomic sites. Therefore, this figure only shows the positions of $\mathrm{Al}(42) \mathrm{a}, \mathrm{Al}(43) \mathrm{a}$, $\mathrm{Pd}(44) \mathrm{a}, \mathrm{Al}(44) \mathrm{c}$ and $\mathrm{Al}(45) \mathrm{b}$. The positions of $\mathrm{Al}(40)$ and $\mathrm{Al}(41)$ with relatively large anisotropic nature are the constituents of the disordered first shell.

[i]

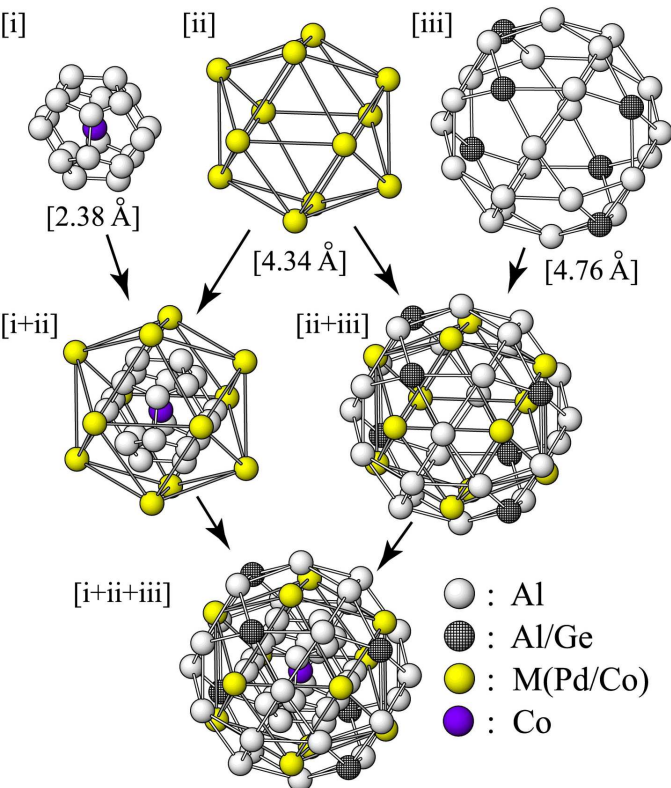

Fig. 2. The pseudo-Mackay cluster around the Co(14) site. The values in the parentheses are the averaged distances of the constituents from the central $\mathrm{Co}(14)$ atom. A dodecahedron consists of statistically occupied $\mathrm{Al}(45)(\mathrm{a}-\mathrm{d})$ sites.

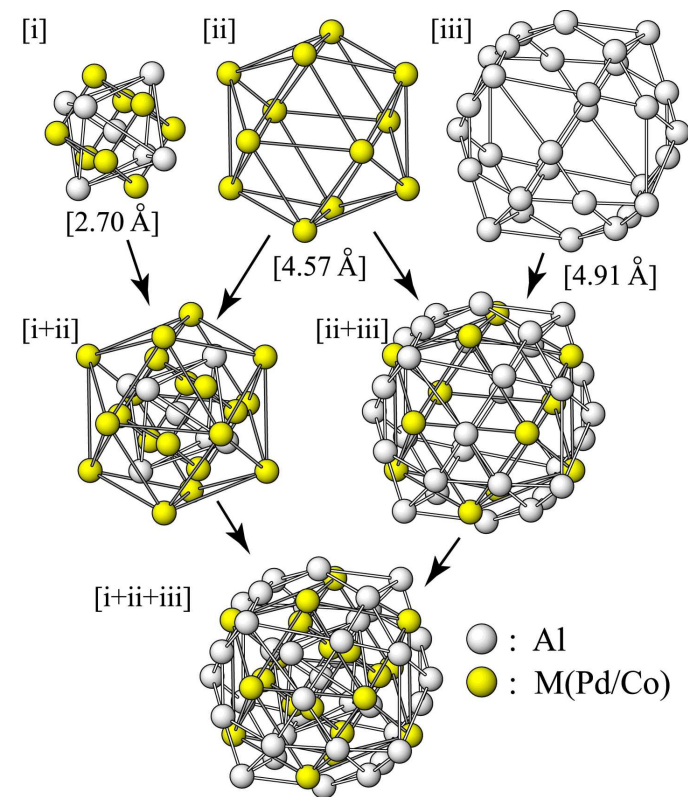

Fig. 3. The pseudo-Mackay cluster around the $\mathrm{Al}(18)$ site. The values in the parentheses are the averaged distances of the constituents from the central $\mathrm{Al}(18)$ atom.

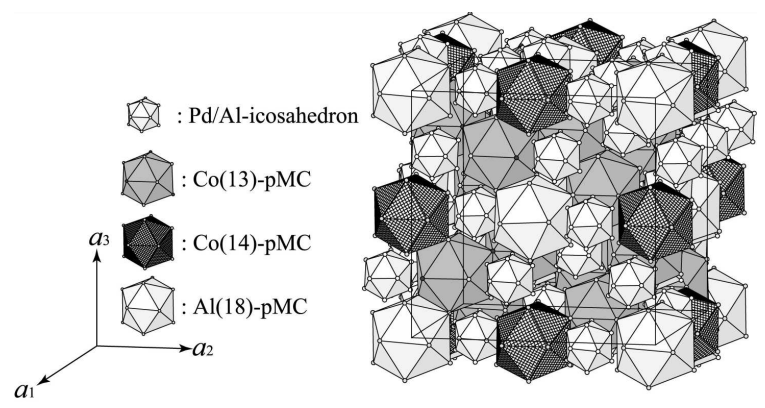

Fig. 4. The structure of the F-AlCoPdGe alloy, which consists of three types of pseudo-Mackay clusters and $\mathrm{Pd} / \mathrm{Al}$ icosahedra.

With this fact in mind, the structure of the $F$-AlCoPdGe alloy could be pictured by the dense packing of the M icosahedra, which were representatives of the pMCs, and small $\mathrm{Pd} / \mathrm{Al}$ icosahedra, as shown in Fig. 4. This figure also implies that the structure could also be represented by the penetration of three types of $\mathrm{pMCs}$ and the $\mathrm{Pd} / \mathrm{Al}$ icosahedra, with no glue atoms being required.

\section{Conclusion}

The structure of the F-AlCoPdGe alloy was determined by single-crystal X-ray diffraction analysis. The structure contains three types of pMCs: those around the $\mathrm{Co}(13)$ sites, those around the $\mathrm{Co}(14)$ sites, and those around the $\mathrm{Al}(18)$ sites. These three types of pMCs could be ranked on the basis of the atomic arrangements of their first shells; nevertheless every outer shell was found to be a combination of an $\mathrm{Al}$ icosidodecahedron and an $\mathrm{M}$ icosahedron, being mainly composed of $\mathrm{Co}$ and $\mathrm{Pd}$. 
These pMCs interpenetrate each other owing to the sharing of the edges of the $\mathrm{M}$ icosahedra, and their interstitial space is subsequently filled by the smaller $\mathrm{Al}$ icosahedra around the $\mathrm{Pd} / \mathrm{Al}(1)$ and $\mathrm{Pd} / \mathrm{Al}(2)$ sites. These structural features suggest that the structure of $F$-AlCoPdGe can be represented suitably by linking the three types of $\mathrm{pMCs}$ and the smaller $\mathrm{Pd} / \mathrm{Al}$ icosahedra without using any glue atom. It should be stressed here that the pMC with interstitial small icosahedra is one of the most important building units for the structure of icosahedral quasicrystal.

\section{Acknowledgments}

This work was supported in part by a Grant-in-Aid for Challenging Exploratory Research (22656153) from the Japan Society for the Promotion of Science (JSPS).

\section{References}

[1] M. Yurechko, B. Grushko, T. Velikanova, K. Urban, J. Alloys Comp. 337, 172 (2002).

[2] Y. Matsuo, K. Hiraga, Philos. Mag. Lett. 70, 155 (1994).

[3] K. Sugiyama, S. Nishimura, K. Hiraga, J. Alloys Comp. 342, 65 (2002).
[4] R. Simura, S. Suzuki, K. Yubuta, K. Sugiyama, Mater. Trans. 54, 1385 (2013).

[5] K. Sugiyama, T. Kato, T. Ogawa, K. Hiraga, K. Saito, J. Alloys Comp. 299, 169 (2000).

[6] S. Suzuki, R. Simura, K. Sugiyama, Philos. Mag. 91, 2610 (2011).

[7] RAPID-AUTO: Rigaku Corporation, Tokyo, Japan 1998.

[8] ABSCOR: T. Higashi, Rigaku Corporation, Tokyo, Japan 1995.

[9] A. Altomare, G. Cascarano, C. Giacovazzo, A. Guagliarde, M.C. Burla, G. Polidori, M. Camalli, J. Appl. Crystallogr. 32, 115 (1999).

[10] R.C. Hudd, W.H. Taylor, Acta Crystallogr. 15, 441 (1962).

[11] J. Grin, U. Burkhardt, M. Ellner, J. Alloys Comp. 206, 243 (1994).

[12] G.M. Sheldrick, Acta Crystallogr. A 64, 112 (2008).

[13] S. Suzuki, R. Simura, K. Sugiyama, Key Eng. Mater. 508, 353 (2012). 